УДК 005.932:631.15

UDC 005.932:631.15

Марчук В.С. ${ }^{1}$, Костюченко Л.В. ${ }^{1}$, Гармаш О.М. ${ }^{1}$, Передерій Н.M. ${ }^{1}$, Градиський Ю.О. ${ }^{2}$

${ }^{1}$ Наиіональний авіачійний університет (м. Київ)

${ }^{2}$ Держсавний біотехнологічний університет (м. Харків)

\title{
КЛЮЧОВІ ЕЛЕМЕНТИ ЛОГІСТИЧНОГО УПРАВЛІННЯ ЗАКУПІВЛЯМИ ДЛЯ ОБОРОННОЇ СФЕРИ
}

\begin{abstract}
Досліджено ключові елементів логістичного управління закупівлями для оборонного сектору у просторі. Встановлено, що тривалість процедури закупівлі на усіх стадіях займає часу набагато більше ніж фізична доставка предмету закупівлі. Причиною цього $є$ де-факто відсутність логістичного управління системою матеріально-технічного забезпечення. Як наслідок - низький рівень практичного запровадження принципів логістики спрямованих на системне управління постачанням, що відповідає концепції логістики НАТО. Логістичне управління закупівлями для оборонного сектору дозволить скоординувати ресурси, техніку, інформацію і людей, оперативно, точно і злагоджено вирішувати поставлені завдання в умовах постійної нестабільності і зміни часових параметрів.

Ключові слова: логістичне управління, закупівлі, система матеріально-технічного забезпечення, принципи логістики постачання, оборонний сектор.
\end{abstract}

\section{ВСТУП}

Сучасні військово-політичні реалії України потребують формування єдиної ефективної системи логістики сил оборони. Основні стратегічні цілі нашої держави в рамках оборонної реформи окреслено у Стратегічному оборонному бюлетені України $[1,2]$ і відповідають Стратегії національної безпеки України щодо забезпечення інтеграції України до Європейського Союзу та формування умов для вступу в НАТО [3, 4]. Отже, стратегічні цілі держави відносно оборонного сектору, мають корелюватися із керівними положеннями, стандартами та інструкціями НАТО 3 логістики. Принциповою метою логістичної системи оборонної сфери $\epsilon$ забезпечення нормального i безперешкодного щоденного життя і підготовки військовослужбовців, а також виконання термінових завдань, які виникають зі специфіки конкретного військового підрозділу чи об'єднання.

\section{АНАЛІЗ ЛІТЕРАТУРНИХ ДАНИХ ТА ПОСТАНОВКА ПРОБЛЕМИ}

Вимоги до формування ефективної політики управління оборонними закупівлями належать до п'яти основних стратегічних цілей в рамках оборонної реформи (п. 4.2. Розділу IV Стратегічного оборонного бюлетеня України до 2020 р.) [2]. Види, причини та наслідки корупційні ризики в державних оборонних закупівлях детально проаналізовані у роботах Голоти О.П. [5] та Бурака М.В. [6]. Вивчення процедур матеріально-технічного забезпечення та закупівель у військовій логістиці $\epsilon$ предметом дослідження науковців та практиків 3 різних сфер та напрямів, у даному матеріалі використані публікації [7-9]. Крім того, в рамках предмета дослідження, автором використано аналіз зміни підходів до управління закупівель у бізнес-середовищі з огляду на глобальні економічні, політичні, інформаційні, соціо-культурні тощо зміни останніх років [10]. В ході опрацювання наукових робіт зазначених авторів, а також низки нормативно-законодавчих актів [11-14], які з-поміж решти трактують вимоги до рівня якості, фінансової ефективності, безпеки закупівель тощо, варто відмітити, що практично відсутнє регулювання часових термінів виконання процедур з матеріальнотехнічного забезпечення.

\section{ЦІЛЬ ТА ЗАДАЧІ ДОСЛІДЖЕННЯ}

3 огляду на наведене постає завдання детальнішого дослідження ключових елементів логістичного управління закупівлями для оборонного сектору у просторі та часі й розробки практичних рекомендацій щодо логістичного управління організацією оборонних закупівель.

\section{РЕЗУЛЬТАТИ ДОСЛІДЖЕНЬ}

Логістична система забезпечується переважно засобом злагодженої роботи елементів макрологістичної системи, але також частково і з цивільного зовнішнього оточення. Залучення підприємств різної форми власності до процесів матеріально-технічного забезпечення підрозділів Збройних Сил вимагає постійного вдосконалення організації і процедур закупівлі товарів, робіт і послуг за державні кошти. Створення у червні 2007 р., відповідно до Закону «Про закупівлю товарів, робіт і послуг за державні кошти» та на підставі рішення Колегії Міністерства оборони єдиний Тендерний комітет Міністерства оборони, дозволило забезпечити більшу прозорість і суворе 
дотримання економічних і правових засад закупівель, раціональне використання державних коштів, посилення контролю на всіх стадіях закупівель, зосередження інформації про централізовані закупівлі в єдиному органі [7]. Однак, державні оборонні закупівлі наразі все ще залишаються «сферою оборонної діяльності, яка $є$ найбільш вразливою до корупційного ризику, причому цей ризик може виникнути на будь-якому етапі закупівельного циклу. Отже, нині в Україні сектор оборони належить до найбільш фінансово містких, оскільки наша держава вимушена захищати свою незалежність, відстоювати територіальну цілісність. На жаль, непосильні для держави оборонні фінансові витрати (понад 80 млрд. грн. на рік) не завжди є транспарентними в практичному використанні» [6].

3 огляду на специфіку функціонування сектору оборони спробуємо порівняти рівень та інтенсивність еволюції підходів до управління закупівлями сектору оборони та цивільного бізнессередовища (див. табл. 1).

Таблиця 1. - Етапи еволюції підходів до управління закупівлями

\begin{tabular}{|c|c|c|}
\hline Сффера & Цивільне бізнес-середовище & Сектор оборони \\
\hline 1 & $\begin{array}{l}\text { Виділення закупівельної функції та } \\
\text { окремих напрямків закупівель }\end{array}$ & $\begin{array}{l}\text { Закупівлі - одна 3-поміж } \\
\text { матеріально-технічного } \\
\text { підрозділів ЗСу }\end{array}$ \\
\hline 2 & $\begin{array}{l}\text { Освітні платформи для фахівців із } \\
\text { закупівель }\end{array}$ & $\begin{array}{l}\text { Освіта в рамках стандартних навчальних планах } \\
\text { військових ВНЗ }\end{array}$ \\
\hline 3 & $\begin{array}{l}\text { Фокус на ланцюгу поставок } \quad \text { i } \\
\text { стратегічній функції закупівель }\end{array}$ & $\begin{array}{llll}\text { Фокус на } & \text { виконанні закупівлі за окремим } \\
\text { договором } & \text { постачання у відриві від решти } \\
\text { закупівель. } & & & \end{array}$ \\
\hline 4 & Діджиталізація закупівель & $\begin{array}{l}\text { Цілісний контроль за виконання незалежно від } \\
\text { реалізаційного періоду постачання }\end{array}$ \\
\hline 5 & $\begin{array}{llll}\begin{array}{l}\text { Консалтинг } \\
\text { закупівлях }\end{array} & \text { та } & \text { аутсорсинг } & \text { y } \\
\end{array}$ & Часткова діджиталізація закупівель \\
\hline
\end{tabular}

Джерело: зведено авторами на основі $[6,7,10]$

Міністерство оборони України здійснює державні закупівлі як централізовано, так i децентралізовано. Причому централізовано здійснює більшість закупівель - на них припадає $90 \%$ потреб [5, с. 8]. Умовно цикл державних оборонних закупівель поділяють на стадії:

1) визначення потреби в певних послугах, обладнанні або роботах (завдання на закупівлю) i планування необхідних закупівель;

2) визначення шляхів придбання необхідного обладнання або послуг для забезпечення цих потреб (визначення процедури закупівлі, вибір джерела постачання, дотримання тендерних процедур);

3) придбання необхідного обладнання або послуг (укладання договору (контракту), управління контрактом, перевірка якості, повноти та своєчасності постачання предмета контракту тощо).

Відповідно до Бюджетного кодексу України, якщо предмет закупівлі не містить відомостей з державної таємниці, закупівельний процес керується законами України «Про публічні закупівлі» та «Про особливості здійснення закупівель товарів, робіт і послуг для гарантованого забезпечення потреб оборони» [7]. Цей Закон регулює своєчасність й ефективність проведення закупівель для потреб Збройних сил України та інших військових формувань в особливий період, період надзвичайного стану та проведення операції Об'єднаних сил [12]. Він передбачає, що під час здійснення закупівель через систему електронних закупівель ProZorro буде істотно посилено відповідальність постачальників за порушення процедури закупівлі та порушення термінів постачання (недобросовісні учасники тендерів нестимуть фінансову відповідальність, втрачатимуть свою репутацію); також відповідно до цього Закону скорочено строки проведення процедур закупівель із 60-ти до 14 днів [6]. Тобто, впроваджено переговорну процедуру на особливий період 3 використанням системи електронних закупівель. Відтак участь компаній у тендерах здійснюватиметься під банківські гарантії, а в разі порушення процедури закупівлі, постачання неякісної продукції або зриву терміну ії постачання банк, який надав гарантію учаснику, сплачуватиме Міністерству оборони України 3 \% від вартості закупівлі [6, 12]. Недобросовісні 
постачальники змушені будуть сплатити гарантійне забезпечення - банківську гарантію, якщо порушать процедуру закупівлі. Також вони потраплять до дискваліфікаційного списку та протягом року не матимуть змоги брати участь у процедурах закупівель Міністерства оборони України та інших силових відомств. Ці фірми оприлюднюватимуть у відповідному розділі порталу державних закупівель [6].

Досліджуючи сутність логістичного забезпечення оборонного сектору, варто розглянути функціонал військової логістики загалом [8]. До таких основних функцій за даними NATO School $\epsilon$ наступні [3]:

- доставка;

- матеріально-технічне забезпечення;

- сервіс;

- технічне обслуговування та ремонт обладнання;

- отримання, планування і подальше переміщення ресурсів;

- переміщення та перевезення;

- забезпечення нафтопродуктами; забезпечення надання медичної допомоги;

- укладення угод;

- підтримка країни, на території якої дислокуються об'єднані сили.

Реалізація логістичного забезпечення оборонного сектору даними NATO School [3] грунтується на досягненні виконання таких умов:

1) створенні тимчасової транспортної інфраструктури (мережі маршрутів та вузлів), спроможної оптимально доставляти предмети логістичного забезпечення споживачам;

2) досягненні умови (обмеження), що чисельність та оснащеність сил на театрі бойових дій не більша ніж вимагає ситуація (зона розташування і передислокації);

3) чітко вибудувана послідовність сил за $4 \mathrm{R}$ (правильні сили, з потрібним обладнанням, у потрібний час, у потрібному місці") - головним правилом військової логістики.

Загалом логістичне управління закупівлями для оборонного сектору (за термінологією НАТО військова логістика) включає п'ять сфер [3]:

1) проектну - проектування і розробка, придбання, зберігання, транспортування, розподіл, догляд, евакуація і розташування озброєння і техніки;

2) транспортну - транспортування особового складу, доставка матеріально-технічних ресурсів;

3) забезпечувальна (постачальницька) - пошук джерел, придбання, будівництво, обслуговування, експлуатація та розташування об'єктів.

4) сервісну - надання різного роду послуг;

5) медичну - матеріально-технічне забезпечення медичних підрозділів.

За даними NATO School [3] за об'єктом спрямованості військової логістики поділяється на два види: колективну та багатонаціональну:

- Колективна логістика передбачає реалізацію національних логістичних можливостей (потужностей) та логістичних можливостей (потужностей) НАТО щодо забезпечення ресурсами та заходами шляхом використання загальних процесів і структур.

- Багатонаціональна логістика передбачає виконання таких операцій:

а) визначення провідної країни у сфері логістики, іiї роль як логістичного експерта та ролі інших країн-учасниць;

б) створення багатонаціонального об'єднаного підрозділу з логістики;

в) організацію тилового забезпечення операцій силами і засобами підрядника.

Зазначений вище функціонал реалізується через виконання параметрів - так званих «5 D» [3]:

1) Destination (призначення) - визначення параметрів потреби;

2) Distance (віддаленість) - визначення стану шляхів сполучення (LOC);

3) Demand (вимога) - визначення ступеня важливості потреби;

4) Duration (тривалість) - визначення необхідної експлуатаційної надійності та необхідності інвестування для потреб забезпечення;

5) Dispersal (розосередження) - визначення загрози LOCs (шляхам сполучення) / MSRs (основним маршрутам постачання).

Невід'ємною умовою реалізації описаних вище функцій і правил є постійне виконання розрахунків оптимізації логістичних компонентів (складових) зони військової присутності, що власне можна вважати метою військової логістики [8]. До прикладу, повноваження з управління військовою 
логістикою надаються командувачу НАТО над тиловими частинами і організаціями, включаючи Національні елементи підтримки (NSE), які дозволяють йому синхронізувати, надати перевагу та інтегрувати функції логістики, необхідні для виконання спільної місії. Це не надає владу над ресурсами, що знаходяться в національній власності, якими володіє NSE, за винятком випадків, узгоджених $з$ передачею повноважень або відповідно до принципів і політики НАТО. По суті, командна структура НАТО погоджує потреби і контролює матеріально-технічне забезпечення для проведення операцій, а країни-партнери мають фізичні можливості для забезпечення власної логістики. Таке співробітництво починається на стадії планування, визначаються загальні завдання й рішення та інформаційні потреби, а вже потім здійснюється планування ресурсного розподілу [2]. Іншими словами, за політикою НАТО, управління логістичною системою оборонної сфери базується на координації усього ланцюга постачання, а власне закупівлі набувають рівня стратегічної функції.

\section{ОБГОВОРЕННЯ РЕЗУЛЬТАТІВ ДОСЛІДЖЕННЯ}

Грунтуючись на наведеному, приходимо до висновку, що логістичне управління закупівлями для оборонного сектору, відповідно до призначення системи логістичного забезпечення готовності до військових операцій, повинна бути спроможною координувати ресурси, техніку, інформацію і людей оперативно, точно, злагоджено в умовах постійної нестабільності і зміни часових параметрів. 3 метою досягнення такої властивості системи логістичного забезпечення військові логісти пропонують інтегрувати проекти NATO Logistics шляхом створення нової структури 3 питань закупівель, приєднання до послуг підтримки та постачання [9].

Дослідження ключових елементів логістичного управління закупівлями для оборонного сектору у просторі та часі показало, що тривалість процедури закупівлі, а саме усіх їі стадій, на практиці займає часу набагато більше ніж фізична доставка предмету закупівлі. Причиною цього $\epsilon$ де-факто відсутність логістичного управління системою матеріально-технічного забезпечення оборонного сектору. Як наслідок - низький рівень практичного запровадження принципів логістики спрямованих на системне управління постачанням, що відповідає концепції логістики НАTO (NATO Logistics).

\section{ВИСНОВКИ}

Перспективні наукові дослідження авторів спрямовані на детальне вивчення операцій закупівель та інших процедур матеріально-технічного забезпечення оборонного сектору у просторі та часі. Визначення «вузьких місць», головних чинників та оцінки їхнього впливу на результати їх виконання. Розробка алгоритму логістичного управління організацією оборонних закупівель в Україні та розробка механізму оптимізації системи управління матеріально-технічним забезпеченням оборонного сектору загалом.

\section{ПЕРЕЛІК ДЖЕРЕЛ ПОСИЛАННЯ}

1. Вонсович О. С. Стратегічний оборонний бюлетень України до 2020 р.: аналітичні оцінки. Гілея: науковий вісник. 2016, Вип. 110. - С. 364-369.

2. Ukrainian Military Pages. Стратегічний бюлетень 2016: система логістики і система медичного забезпечення. [сайт]. URL: https://www.ukrmilitary.com/2016/06/sob2016-logistik-and-medicine.html

3. Дре Керстьєнс. Логістичне планування НАTO та сучасні виклики. NATO School (22.04.2016). Головна сторінка Національного університету оборони України ім. I. Черняховського [сайт]. URL: https://nuou.org.ua/assets/documents/logstichne-planuvannya-nato-ta-suchasn-vikliki.pdf

4. NATO Logistics Handbook/ Third Edition: October 1997, [сайт]. URL: https://www.nato.int/docu/logi-en/logist97.htm

5. Голота О. П. Ризики корупції в державних оборонних закупівлях. Науковий центр проблем запобігання корупції в секторі безпеки та оборони, Національний університет оборони України імені $\begin{array}{llll}\text { Iвана Черняховського. 2018. [сайт]. URL: http://bitec.nuou.org.ua/wp- } & \end{array}$ content/uploads/2018/12/MOD AC BITEC Presentation ukr.pdf

6. Бурак М. В. Корупційні ризики в державних оборонних закупівлях: шляхи мінімізації. Юридичний часопис Національної академії внутрішніх справ № 2 (18) 2019. C. 103-115. [сайт]. URL: http://elar.naiau.kiev.ua/bitstream/123456789/15126/1/14.pdf

7. Неуров І.В. Постачання та закупівлі у військовій логістиці. Системи озброєння і військова техніка: Військово-технічні проблеми, 2008, № 2(14). С. 58-60.

8. Kostyuchenko L., Solomon D. (2020) "The basic terminology of the modern military logistics". Intellectualization of logistics and Supply Chain Management. [Online], vol.1, p.91-98, available at: 
https://smart-scm.org/en/journal-1-2020/lesia-kostiuchenko-solomon-dmitry-the-basic-terminology-of-themodern-military-logistics/ (Accessed 30 May 2020).

9. Kostiuchenko L.V., Kostiuchenko A.V. (2020) "The logistical support system elements for the preparedness for military operations". Intellectualization of logistics and Supply Chain Management. [Online], vol.2, pp.16-31, available at: https://smart-scm.org/en/journal-2-2020/lesia-kostiuchenko-andriikostiuchenko-the-logistical-support-system-elements-for-the-preparedness-for-military-operations/ (Accessed 24 July 2020).

10. Трепова М. Еволюція закупівель: топ-5 змін в Україні: Діджиталізація і аутсорсинг: як змінилися закупівлі в Україні за 10 років. 2020. [caüm]. URL: https://mind.ua/openmind/20208464evolyuciya-zakupivel-top-5-zmin-v-ukrayini

11. Про Стратегію національної безпеки України: Указ президента України за станом на 14 вересня 2020 року [caŭm]. URL: https://zakon.rada.gov.ua/laws/show/392/2020\#Text (Указ президенту України)

12. Про особливості здійснення закупівель товарів, робіт і послуг для гарантованого забезпечення потреб оборони: Закон України за станом на 12 травня 2016 р. № 1356-VIII. [caŭm]. URL: https://zakon.rada.gov.ua/laws/show/1356-19

13. Про публічні закупівлі: Закон України за станом на 25 грудня 2015 р. № 922-VIII. [caŭm]. URL: https://zakon.rada.gov.ua/laws/show/922-19

14. Про реформування оборонно-промислового комплексу та підвищення рівня прозорості виконання державного оборонного замовлення : Указ Президента України за станом на 15 березня 2019 p. № 79/2019. [caüm]. URL: https://zakon.rada.gov.ua/laws/show/n0001525-19.

\section{REFERENCES}

1. Vonsovych O. S. Stratehichnyy oboronnyy byuleten Ukrayiny do 2020 r.: analitychni otsinky. Hileya: naukovyy visnyk. 2016, Vyp. 110. - S. 364-369.

2. Ukrainian Military Pages. Stratehichnyy byuleten 2016: systema lohistyky i systema medychnoho zabezpechennya. [sayt]. URL: https://www.ukrmilitary.com/2016/06/sob2016-logistik-and-medicine.html

3. Dre Kerstyens. Lohistychne planuvannya NATO ta suchasni vyklyky. NATO School (22.04.2016). Holovna storinka Natsionalnoho universytetu oborony Ukrayiny im. I. Chernyakhovskoho [sayt]. URL: https://nuou.org.ua/assets/documents/logstichne-planuvannya-nato-ta-suchasn-vikliki.pdf

4. NATO Logistics Handbook/ Third Edition: October 1997, [sayt]. URL: https://www.nato.int/docu/logi-en/logist97.htm

5. Holota O. P. Ryzyky koruptsiyi $\mathrm{v}$ derzhavnykh oboronnykh zakupivlyakh. Naukovyy tsentr problem zapobihannya koruptsiyi v sektori bezpeky ta oborony, Natsionalnyy universytet oborony Ukrayiny imeni Ivana Chernyakhovskoho. 2018. [sayt]. URL: http://bitec.nuou.org.ua/wpcontent/uploads/2018/12/MOD_AC_BITEC_Presentation_ukr.pdf

6. Burak M. V. Koruptsiyni ryzyky v derzhavnykh oboronnykh zakupivlyakh: shlyakhy minimizatsiyi. Yurydychnyy chasopys Natsionalnoyi akademiyi vnutrishnikh sprav № 2 (18) 2019. S. 103-115. [sayt]. URL: http://elar.naiau.kiev.ua/bitstream/123456789/15126/1/14.pdf

7. Neurov I.V. Postachannya ta zakupivli u viyskoviy lohistytsi. Systemy ozbroyennya i viyskova tekhnika: Viyskovo-tekhnichni problemy, 2008, № 2(14). S. 58-60.

8. Kostyuchenko L., Solomon D. (2020) "The basic terminology of the modern military logistics". Intellectualization of logistics and Supply Chain Management. [Online], vol. 1, p. 91-98, available at: https://smart-scm.org/en/journal-1-2020/lesia-kostiuchenko-solomon-dmitry-the-basic-terminology-of-themodern-military-logistics/ (Accessed 30 May 2020).

9. Kostiuchenko L.V., Kostiuchenko A.V. (2020) "The logistical support system elements for the preparedness for military operations". Intellectualization of logistics and Supply Chain Management. [Online], vol. 2, pp. 16-31, available at: https://smart-scm.org/en/journal-2-2020/lesia-kostiuchenko-andriikostiuchenko-the-logistical-support-system-elements-for-the-preparedness-for-military-operations/

(Accessed 24 July 2020).

10. Trepova M. Evolyutsiya zakupivel: top-5 zmin v Ukrayini: Didzhytalizatsiya i aut·sorsynh: yak zminylysya zakupivli v Ukrayini za 10 rokiv. 2020. [sayt]. URL: https://mind.ua/openmind/20208464evolyuciya-zakupivel-top-5-zmin-v-ukrayini

11. Pro Stratehiyu natsionalnoyi bezpeky Ukrayiny: Ukaz prezydenta Ukrayiny za stanom na 14 veresnya 2020 roku [sayt]. URL: https://zakon.rada.gov.ua/laws/show/392/2020\#Text (Ukaz prezydentu Ukrayiny) 
12. Pro osoblyvosti zdiysnennya zakupivel tovariv, robit i posluh dlya harantovanoho zabezpechennya potreb oborony: Zakon Ukrayiny za stanom na 12 travnya 2016 r. № 1356-VIII. [sayt]. URL: https://zakon.rada.gov.ua/laws/show/1356-19

13. Pro publichni zakupivli: Zakon Ukrayiny za stanom na 25 hrudnya 2015 r. № 922-VIII. [sayt]. URL: https://zakon.rada.gov.ua/laws/show/922-19

14. Pro reformuvannya oboronno-promyslovoho kompleksu ta pidvyshchennya rivnya prozorosti vykonannya derzhavnoho oboronnoho zamovlennya : Ukaz Prezydenta Ukrayiny za stanom na 15 bereznya 2019 r. № 79/2019. [sayt]. URL: https://zakon.rada.gov.ua/laws/show/n0001525-19.

\section{Marchuk, L. Kostyuchenko, O. Garmash, N. Perederiy, Y. Gradysky. Key elements of logistic procurement management for the defense sphere.}

The key elements of logistics procurement management for the defense sector in space are studied. It is established that the duration of the procurement procedure at all stages takes much longer than the physical delivery of the subject of procurement. The reason for this is the de facto lack of logistics management of the logistics system. As a result, there is a low level of practical implementation of logistics principles aimed at systematic supply management, which is in line with the concept of NATO logistics. Logistics procurement management for the defense sector will allow to coordinate resources, equipment, information and people, quickly, accurately and coherently solve the tasks in conditions of constant instability and changes in time parameters.

The study of key elements of logistics procurement management for the defense sector in space and time showed that the duration of the procurement procedure, namely all its stages, in practice takes much longer than the physical delivery of the subject of procurement. The reason for this is the de facto lack of logistical management of the logistics system of the defense sector. As a result, there is a low level of practical implementation of logistics principles aimed at systematic supply management, which is in line with the concept of NATO logistics (NATO Logistics).

Promising research of the authors is aimed at a detailed study of procurement operations and other procedures of logistics of the defense sector in space and time. Identification of "bottlenecks", the main factors and assessment of their impact on the results of their implementation. Development of an algorithm for logistics management of the organization of defense procurement in Ukraine and development of a mechanism for optimizing the management system of logistics of the defense sector in general.

Key words: logistics management, procurement, logistics system, principles of supply logistics, defense sector.

МАРЧУК Володимир Єфремович, доктор технічних наук, професор, професор кафедри логістики, Національний авіаційний університет, (м. Київ) e-mail: sunduk_2005@ukr.net https://orcid.org/0000-0003-0140-5416

КОСТЮЧЕНКО Леся Вячеславівна, кандидат економічних наук, доцент, доцент кафедри логістики, Національний авіаційний університет, (м. Київ) e-mail: lesia.kost@gmail.com https://orcid.org/0000-0002-7635-5153

ГАРМАШ Олег Миколайович, кандидат економічних наук, доцент, доцент кафедри логістики, Національний авіаційний університет, Кйї) (м. е-mail: oleh.harmash@npp.nau.edu.ua https://orcid.org/0000-0003-4324-4411

ПЕРЕДЕРІЙ Надія Миколаївна, кандидат економічних наук, доцент, доцент кафедри організації авіаційних перевезень, Національний авіаційний університет (м. Київ) e-mail: nadiyka.gavriljuk@gmail.com https://orcid.org/0000-0003-4173-9445

ГРАДИСБКИЙ Юрій Олександрович, кандидат технічних наук, доцент, доцент кафедри деревооброблювальних технологій та системотехніки лісового комплексу, Державний біотехнологічний університет (м. Харків) e-mail: gradiskiy@ btu.kharkov.ua https://orcid.org/0000-0002$\underline{5226-6252}$

Volodymyr MARCHUK, Doctor of Technical Sciences, Professor, Professor of the Department of Logistics, National Aviation University, Kyiv e-mail: sunduk_2005@ukr.net https://orcid.org/0000-00030140-5416

DOI 10.36910/automash.v2i17.639 